\title{
Content and composition of essential oil in lemon balm (Lippia alba (Mill) N.E.Br.) grown with ammonium and nitrate in light environments
}

\section{Aceite esencial de cidrón (Lippia alba (Mill) N.E.Br.) cultivada con proporciones de amonio y nitrato y entornos de luz}
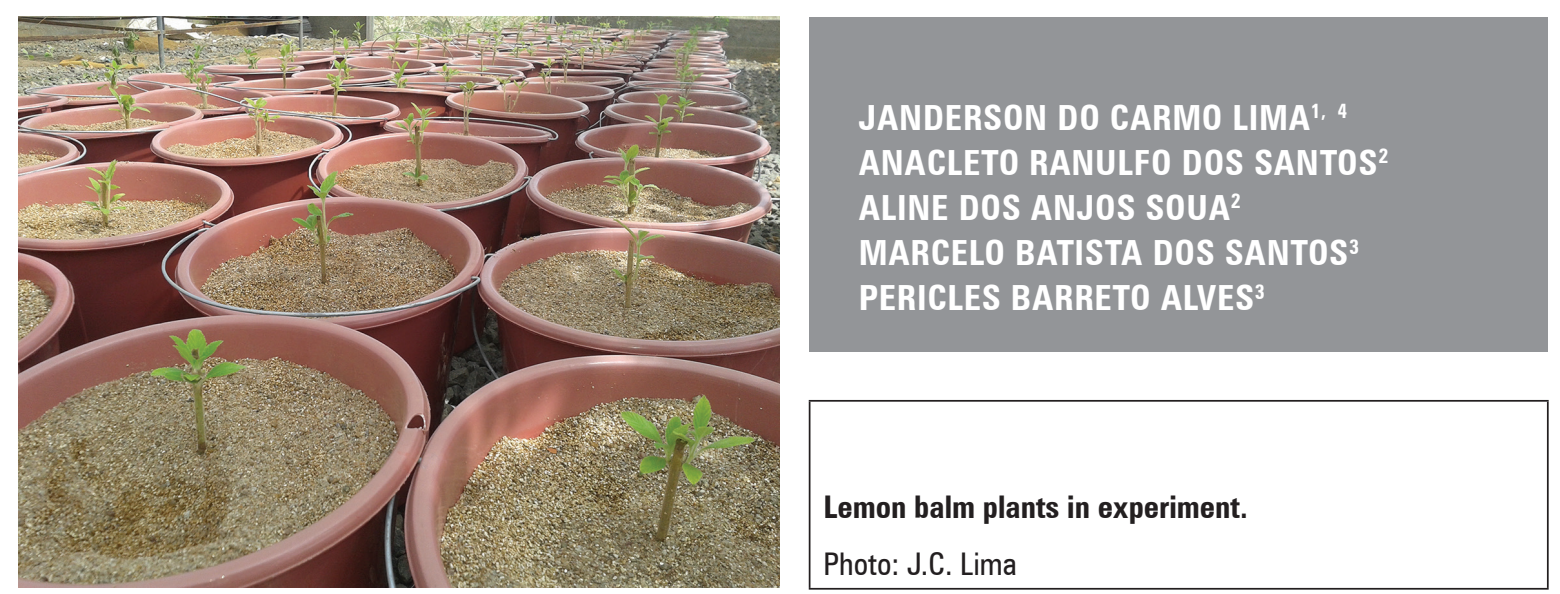

\begin{abstract}
Medicinal plants have great potential for the production of phytocompounds, which are used for various purposes, mainly in drugs and cosmetics. The aim of this study was to evaluate the essential oil from Lippia alba cultivated with ammonium $\left(\mathrm{NH}_{4}{ }^{+}\right)$and nitrate $\left(\mathrm{NO}_{3}{ }^{-}\right)$under light environments. The plants were subjected to five ratios of $\mathrm{NH}_{4}{ }^{+}$: $\mathrm{NO}_{3}{ }^{-}$with nutritious solutions and four light environments (red, aluminet and black mesh, and full sun). The experiment design was entirely randomized with a $5 \times 4$ interaction and five repetitions per treatment, totaling 100 experiment units. The seedlings were transplanted to $6 \mathrm{dm}^{3}$ plastic pots containing a mixture of washed sand + vermiculite at a ratio of 2:1. At 120 days after application of the treatments, the following parameters were evaluated: yield, content and composition of essential oil. The extraction was performed with the hydrodistillation method using drag of steam for a period of 2 hours. Nine compounds were found in the essential oil, of which neral and geranial represented $90 \%$ of the blend. Carvone was only found in the treatment with plants grown under the red mesh and with the 50:50 ratio of ammonium and nitrate.
\end{abstract}

\footnotetext{
Additional key words: essences (essential oils); artificial light; nitrogen; secondary metabolism.

Universidade Estadual de Feira de Santana, Doutorando em Recursos Geneticos Vegetais, Feira de Santana (Brazil). ORCID Lima, J.C.: 0000-0002-7564-5044

2 Universidade Federal do Recôncavo da Bahia, Centro de Ciencias Agrarias Ambientais, Cruz das Almas (Brazil). ORCID Santos, A.R.: 0000-0003-4629-3948; ORCID Soua, A.A.: 0000-0003-1522-574X

3 Universidade Federal de Sergipe, Sao Cristovao (Brazil). ORCID Santos, M.B.: 0000-0002-3501-4475; Alves, P.B.: 00000002-8955-9614

4 Corresponding author.janderson_ufrb@yahoo.com.br
} 


\section{RESUMEN}

Las plantas medicinales tienen un gran potencial en la producción de fitocompuestos, estos son derivados para fines diversos, principalmente en la industria de medicamentos y cosméticos. El objetivo de este estudio fue evaluar el aceite esencial de Lippia alba, cultivada con proporciones de amonio $\left(\mathrm{NH}_{4}{ }^{+}\right)$y nitrato $\left(\mathrm{NO}_{3}{ }^{-}\right)$en entornos de luz. Las plantas fueron sometidas a cinco proporciones de $\mathrm{NH}_{4}{ }^{+}$: $\mathrm{NO}_{3}{ }^{-}$, adicionados por soluciones nutritivas, y cuatro ambientes de luz (mallas roja, aluminet y negra, y solar completo). El diseño experimental fue completamente al azar con la interacción $5 \times 4$, con 5 repeticiones por tratamiento, para un total de 100 unidades experimentales. Las plántulas fueron transplantadas a macetas de plástico $6 \mathrm{dm}^{3}$ de capacidad, conteniendo una mezcla de arena lavada + vermiculita en relación 2:1. Después de 120 días de la aplicación de los tratamientos, los parámetros evaluados fueron rendimiento, contenido de humedad y la composición del aceite esencial. La extracción se realizó a través de hidrodestilacion por arrastre de vapor, para un período de 2 horas. Se encontraron nueve compuestos en los aceites esenciales, el geranial y neral representaron el $90 \%$ de la mezcla, la carvona sólo se encontró en el tratamiento con plantas cultivadas bajo malla roja y con la relación de 50:50 de amonio y nitrato.

Palabras clave adicionales: esencias (aceites esenciales); luz artificial; nitrógeno; metabolismo secundario.

Received for publication: 22-03-2018 Accepted for publication: 29-03-2019

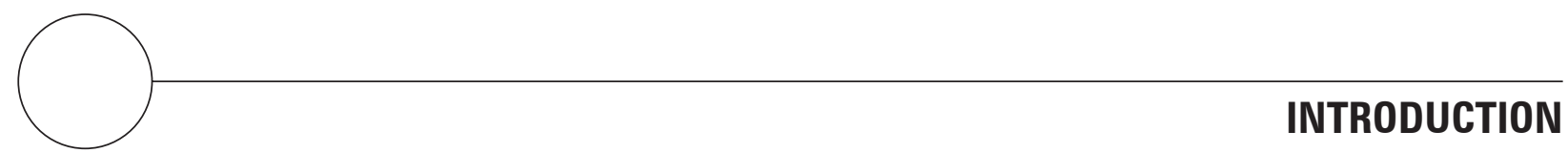

Medicinal and aromatic plants are well known and have high acceptability by the world, including lemongrass (Lippia alba (Mill) N.E.Br.), also known as lemon balm, Brazilian lemongrass, field lemon balm, false melissa, field rosemary, wild rosemary, and wild cider, among others (Carmona et al., 2013; Ehlert et al., 2013). It has great economic importance domestically because of its essential oils, which have biochemicals that are of great interest for drugs since they have scientifically verified therapeutic action, besides important groups of raw material for perfumery and industries (Soares and Dias, 2013; Luz et al., 2014) and soothing, mild antispasmodic, analgesic, sedative, anxiolytic, and slightly expectorant properties (Matos et al., 2000; Nascimento et al., 2013). It also has some compounds with antiprotozoal, bactericidal and fungicidal activities (Tavares et al., 2011).

The essential oils may have different biological properties, such as a larvicidal, antioxidant, analgesic, anti-inflammatory and fungicide action (Rajkumar and Jebanesan, 2010). These oils are produced by the activation of the secondary metabolism of the plants. Factors that promote the activation of the secondary metabolism include luminosity and mineral nutrition, which are primordial for the physiological characteristics and increase vegetal production (Corrêa et al., 2009; Meira et al., 2012). Luminosity, which is essential for photosynthesis, has been studied for many years. Colored mesh, also called photoconverters, alters the spectral quality provided to plants and produces significant physiological responses in several plants (Souza et al., 2011).

Another indispensable factor for plant performance is mineral nutrition. Plants have macro and micronutrient requirements, including nitrogen $(N)$, which is normally required in a greater quantity and is directly related to plant metabolism, making up constituents of important biomolecules (Bredemeier and Mundstock, 2000).

This nutrient can be absorbed in its cationic or anionic form and influences the metabolism of some plants. While studying the relationship between ammonium and nitrate, Alves et al. (2013) found that the dry mass yield of sunflower plants was significantly influenced by $\mathrm{NH}_{4}^{+}$and $\mathrm{NO}_{3}^{-}$ratios, concluding that, when nitrogen was supplied only in the ammoniacal form, the dry mass was severely reduced, about 38\% lower for the dry mass of the aerial part, as compared to the treatment with nitrogen only in the nitric form.

When using different ratios of ammonium and nitrate in the nutrient solution for a lettuce crop, Ohse et al. (2017) concluded that the $\mathrm{NH}_{4}{ }^{+}$concentration should not exceed $20 \%$ of the total nitrogen because 
it causes reductions in both the yield and visual quality of plants.

Therefore, the objective of this study was to evaluate the content, yield and chemical composition of essential oils from lemon grass cultivated with ammonium and nitrate under colored mesh.

\section{MATERIAL AND METHODS}

L. alba seedlings were produced from cuttings in a nursery belonging to the Center for Agrarian, Environmental and Biological Sciences of the Federal University of Recôncavo da Bahia (UFRB), Cruz das Almas-BA, Brazil. The branches used for the cuttings were produced from a matrix plant, a species that has been identified, and the exsicata is deposited in the Herbarium of the University, located in Cruz das Almas-BA, with plant trowel number HURB 8806.

The plant material was rooted in a substrate containing washed sand in polyethylene trays. After rooting, the plants with a mean height of 10 $\mathrm{cm}$ and root length of $12 \mathrm{~cm}$ were selected and transplanted to plastic vessels containing $6 \mathrm{dm}^{3}$ of washed sand + vermiculite at a 2:1 ratio.

The experiment was carried out in the experimental field of the Center for Agrarian, Environmental and Biological Sciences of the Universidade Federal do Recôncavo da Bahia (UFRB), in the municipality of Cruz das Almas-Bahia (1240" S and 39 $06^{\circ}$ "W, 226 m a.s.l.) from December, 2015 to April, 2016.

The experiment design was completely randomized in a $5 \times 4$ factorial scheme, with five ratios of ammonium and nitrate (100:0, 75:25, 50:50, 25:75 and $0: 100)$ (Tab. 1) and four light environments, obtained using the colored red wavelength of $770 \mathrm{~nm}$, black (shading only) and aluminized (thermal control) ChromatiNet $^{\circledR}$ mesh (Polysack Plastic Industries, Negev, Israel) and full sun treatment, used as the control. Each treatment contained five replicates, one plant per pot, totaling 100 experiment units. The treatments were established based on the nitrogen (N) concentration in the solution from Hoagland and Arnon (1950). The nutrient solution was composed of macro and micronutrients, in concentrations of $\mathrm{mg} \mathrm{L}^{-1}: \mathrm{N}=210, \mathrm{P}=31, \mathrm{~K}=234, \mathrm{Ca}=200, \mathrm{Mg}=48$ and $\mathrm{S}=64$, with $\mathrm{pH}=5.6( \pm 1)$. The distribution of the treatments was started $8 \mathrm{~d}$ after transplant and acclimatization of the seedlings.

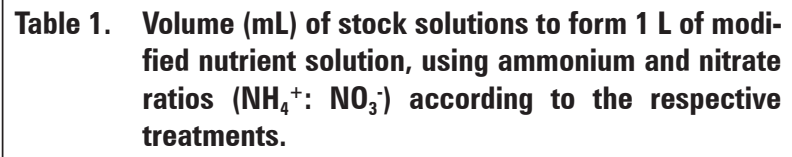

\begin{tabular}{|c|c|c|c|c|c|}
\hline \multirow{3}{*}{$\begin{array}{l}\text { Stock solution } \\
\text { (1 Molar) }\end{array}$} & \multicolumn{5}{|c|}{ Proportions of $\mathrm{NH}_{4}{ }^{+}: \mathrm{NO}_{3}$} \\
\hline & 100:0 & $75: 25$ & $50: 50$ & $25: 75$ & $0: 100$ \\
\hline & \multicolumn{5}{|c|}{$(\mathrm{mL})$} \\
\hline $\mathrm{KH}_{2} \mathrm{PO}_{4}$ & 1.0 & 1.0 & 1.0 & 1.0 & 1.0 \\
\hline $\mathrm{NH}_{4} \mathrm{Cl}$ & 15.0 & 11.25 & 7.5 & 3.75 & - \\
\hline $\mathrm{KCl}$ & 5.0 & 1.25 & 5.0 & 3.75 & - \\
\hline $\mathrm{CaCl}_{2}$ & 5.0 & 5.0 & 1.25 & - & - \\
\hline $\mathrm{MgSO}_{4}$ & 2.0 & 2.0 & 2.0 & 2.0 & 2.0 \\
\hline $\mathrm{KNO}_{3}$ & - & 3.75 & - & 1.25 & 5.0 \\
\hline $\mathrm{Ca}\left(\mathrm{NO}_{3}\right)_{2}$ & - & - & 3.75 & 5.0 & 5.0 \\
\hline Micronutrients $^{1}$ & 1.0 & 1.0 & 1.0 & 1.0 & 1.0 \\
\hline Iron - EDTA2 ${ }^{2}$ & 1.0 & 1.0 & 1.0 & 1.0 & 1.0 \\
\hline
\end{tabular}

'Micronutrient solution (g L $\left.{ }^{-1}\right): \mathrm{H}_{3} \mathrm{BO}_{3}=2.86 ; \mathrm{MnCl}_{2} 4 \mathrm{H}_{2} \mathrm{O}=1.81 ; \mathrm{ZnCl}_{2}=0.10$; $\mathrm{CuCl}_{2}=0.04 ; \mathrm{H}_{2} \mathrm{MoO}_{4} \mathrm{H}_{2} \mathrm{O}=0.02$. ${ }^{2}$ Iron-EDTA solution: $26.1 \mathrm{~g}$ of disodium EDTA were dissolved in $286 \mathrm{~mL}$ of $1 \mathrm{~N} \mathrm{NaOH}+24.9 \mathrm{~g}$ of $\mathrm{FeSO}_{4} .7 \mathrm{H}_{2} \mathrm{O}$ and aerated overnight.

\section{Extraction of essential oil}

The extraction of essential oil from the L. alba plants was carried out at the Phytochemical Laboratory of UFRB. At $120 \mathrm{~d}$ after the application of the treatments, leaves were collected to obtain the essential oil, which were individually packed in paper sacks, dried in a forced air oven at $45^{\circ} \mathrm{C}$ for $96 \mathrm{~h}$. Afterwards, they were weighed to obtain the dry mass (g) and used for extraction of essential oil with the hydrodistillation method using drag of water vapor, equipped with a Clevenger graduated device (Santos, 2004; Oliveira et al., 2012).

One gram of dried phytomass at $40^{\circ} \mathrm{C}$ was used to determine the variation in the moisture content, and the samples were dehydrated at a temperature of $100^{\circ} \mathrm{C}$ to constant weight. It was necessary to join the dry material of each ammonium and nitrate ratio within each light environment to obtain the amount of phytomass sufficient for extraction of the oil, according to the methodology. Five grams of each sample were placed in a $1 \mathrm{~L}$ glass flask containing distilled water in sufficient volume to cover the plant material. Graduated Clevenger type appliances were used, coupled to the glass flasks, heated with thermostatic electric blankets. The extraction process was conducted for $2 \mathrm{~h}$, counted from the condensation of the first drop of essential oil, and the volume extracted in 
the graduated column of the Clevenger was verified. Subsequently, using the Pasteur-type pipette, the oil was packed in a $2 \mathrm{~mL}$ glass jar, labeled and stored in a commercial freezer at $-5^{\circ} \mathrm{C}$ until the chemical analysis was performed.

\section{Obtaining essential oil content and yield}

According to Santos (2004), the calculation of the content of essential oil (Eq. 1) was carried out with the moisture free base (BFM), which corresponded to the volume $(\mathrm{mL})$ of essential oil in relation to the dry mass.

$$
\text { To: } \frac{V_{0}}{M s-U} \times 100
$$

where $T_{0}$ is the oil content (\%), Vo is the volume of oil extracted, $M s$ is the dry mass and $U$ is the moisture present in dry mass.

The yield of the oil was obtained with the value of the content/100 and multiplied by the total dry mass of the leaves.

\section{Analysis of oils}

The qualitative determination was carried out in the natural products laboratory of the Federal University of Sergipe (UFS), and the essential oil analysis was performed with gas chromatography coupled to a CG-EM mass spectrometry (Shimidzu Corporation, Japan, model OP 5050A), equipped with an AOC -20i autosampler (Shimadzu) and DB-5 fused silica capillary column $(30 \mathrm{~m} \times 0.25 \mathrm{~mm}$ id, $0.25 \mu \mathrm{m}$ film). Then, the following conditions were carried out: electron impact ionization at $70 \mathrm{eV}$; helium as the carrier gas and flow rate of $1 \mathrm{~mL} / \mathrm{min}$; an injector in the split mode (1:83) injected a volume of $0.5 \mu \mathrm{L}$ in ethyl acetate; injected volume partition ratio of 1:83 and column pressure of $64.20 \mathrm{kPa}$; increasing temperature gradient of $4^{\circ} \mathrm{C} / \mathrm{min}, 40$ to $200^{\circ} \mathrm{C}$ and $20^{\circ} \mathrm{C} /$ min, 200 to $280^{\circ} \mathrm{C}$. The injector and detector temperatures were 250 and $280^{\circ} \mathrm{C}$, respectively. The mass spectra were obtained with the scan method and a scanning range of 0.50 fragments/s in the range $\mathrm{m} / \mathrm{z}$ 40 - 450 Da.

The quantitative analysis of the constituents was done with a gas chromatograph equiped with a flame ionization detector using a Shimadzu GC-17 device under the following operating conditions: ZB-5MS fused silica capillary column (5\% dimethylpolysiloxane) with $30 \mathrm{~m} \times 0.25 \mathrm{~mm}$ i.d. $\times 0.25 \mu \mathrm{m}$ film, using the same CG-EM conditions.

\section{Identification of chemical constituents}

The oil was analyzed simultaneously with Gas Chromatography coupled to Mass Spectrometry (GC-MS) and Gas Chromatography with a Flame Ionization Detector (GC-FID) using a GC-2010. The qualitative analysis of the essential oils was carried out with $\mathrm{CG} / \mathrm{EM}$, while the percentage of the individual constituents was determined with CG/DIC, obtained using a detector separation system; the flow separation ratio was 4:1 (MS-FID), where the content of each component was determined based on the area of each peak related to the total area of the peaks in the chromatogram.

Each component of the oil was identified based on the retention time (considering a homologous series of C8-C18 n-alkanes), retention index (IR) applying the Dool and Kratz equation, corrected with linear regression, as well as comparing the fragmentation pattern of each component with the virtual database mass spectra (Library NIST107, NIST21 e Willey 8) and with visual comparison using the mass spectra recorded in the literature (Adams, 2007).

During the chemical analyses, the sample containing the oil of leaves grown with $100 \% \mathrm{NH}_{4}{ }^{+}$in full sun was lost because a contact reaction occurred, which made it impossible to read in the chromatograph.

\section{RESULTS AND DISCUSSION}

For the essential oil contents that were extracted (Fig. 1), it was verified that the plants grown in the nutrient solution containing the 50:50 ratio of $\mathrm{NH}_{4}{ }^{+}: \mathrm{NO}_{3}{ }^{-}$presented the highest average percentage value, followed by those grown with $100 \%$ of the ion ammonium under the black mesh. This was possibly due to metabolic changes during the absorption and assimilation of ammonium. For the light environments, it was observed that the plants cultivated under the black mesh presented average values higher than the others (3.12\% on average), followed by red $(2.86 \%)$ and full sun $(2.94 \%)$.

Working in modified light environments, Chagas et al. (2013) observed that, in Japanes pepper mint plants, 
the production of essential oil was more influenced by intensity than by quality of the light. While also 1 studying light environments, Oliveira et al. (2016), found that the highest oil contents extracted from oregano plants were found in those grown under full sun. Changes in the essential oil content of Lippia sidoides were found by Souza et al. (2007) when these plants were cultivated under different percentages $(75,50$ and $25 \%)$ of shading. The effects of intensity and luminous quality vary according to the species, showing the particularities of each species.

As for the essential oil yield of L. alba (Fig. 2), the yield was similar to that found for the content (Fig. 1), where the nutrient solution containing $50: 50 \mathrm{NH}_{4}{ }^{+}$: $\mathrm{NO}_{3}^{-}$had a positive influence, obtaining the highest average value, followed by the treatment with $100 \%$ ammonium. For the light environments, the plants grown under the red mesh presented average values higher than the others $\left(0.42 \mathrm{~g} \mathrm{~kg}^{-1}\right)$, followed by those grown under the black mesh $\left(0.40 \mathrm{~g} \mathrm{~kg}^{-1}\right)$ and aluminet mesh $\left(0.38 \mathrm{~g} \mathrm{~kg}^{-1}\right)$, emphasizing the affinity of this species with the light environments.

The essential oil yield varies from species to species and depends on several factors and conditions of cultivation; usually, a higher oil yield is the result of a greater accumulation of phytomass (Pinto et al., 2014). According to Rao (2001), most aromatic plants are sensitive to $\mathrm{N}$ deficiencies, and the application of $\mathrm{N}$ increases the production of essential oil. The metabolites produced depend on the primary metabolism of carbon, which can be divided into three distinct groups: terpenes, phenolic compounds and nitrogen compounds. These products come from the different carbons. High concentrations of $\mathrm{N}$ increase the demand of $\mathrm{CH}_{2} \mathrm{O}$ for its assimilation and, consequently, energy consumption, competing with the

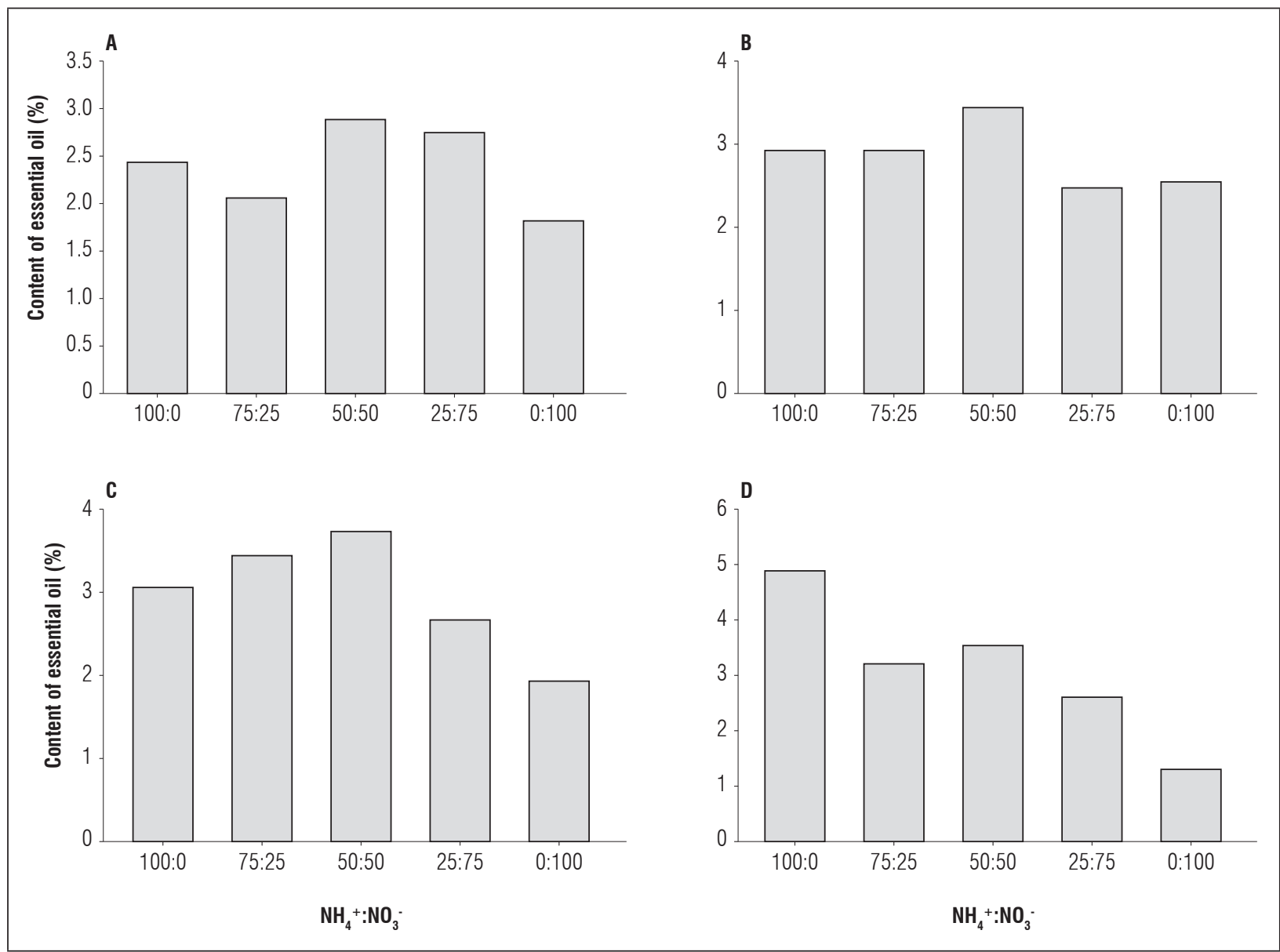

Figure 1. Content of essential oil of Lippia alba plants grown with $\mathrm{NH}_{4}{ }^{+}: \mathrm{NO}_{3}{ }^{-}$ratios and light environments: $\mathrm{A}$, aluminet mesh; $\mathrm{B}$, red mesh; C, full sun; D, black mesh. 
primary metabolism and compromising the synthesis of these compounds (Taiz and Zeiger, 2013). It is extremely important to highlight the composition of these secondary metabolites since they are used for the production of cosmetics and pharmaceuticals, making it a very important raw material (Linde et al., 2016).

Among all the compounds found in the essential oil of $L$. alba leaves grown under light environments and nutrient solutions containing ammonium and nitrate, the ones that were more prominent in all the treatments were neral and geranial (Tab. 2 and 3), representing $90 \%$ of the total compounds. According to Budavari (1989), citral is a result of the mixture of geranial(citral a), and neral isomers(citral b) and has a citric odor, which is why it is used in the manufacture of certain products.
Nine different compounds were found in the Lippia essential oil when cultivated in light and $\mathrm{N}$ (Tab. 2 and 3), including: myrcene, p-cymene, linalool, neral, carvone, geranial, caryophyllene oxide, (E)caryophyllene, terpinen-4-ol/E-isocitral, eugenol and humulene epoxide II.

The highest concentration of neral was found (Tab. 3 ) in the plants grown with $100 \% \mathrm{NO}_{3}{ }^{-}$and under the full sun environment $(48.01 \%)$, while the geranial compound had its highest content (58.2\%) in the plants grown in full sun and nutrient solutions containing the $75: 25$ ratio of $\mathrm{NH}_{4}{ }^{+}: \mathrm{NO}_{3}$. Probably, this happened because of the phenomenon of $\mathrm{N}$ nitrate absorption in relation to the ammoniacal, associated with the condition for photosynthetic activity provided by this environment.
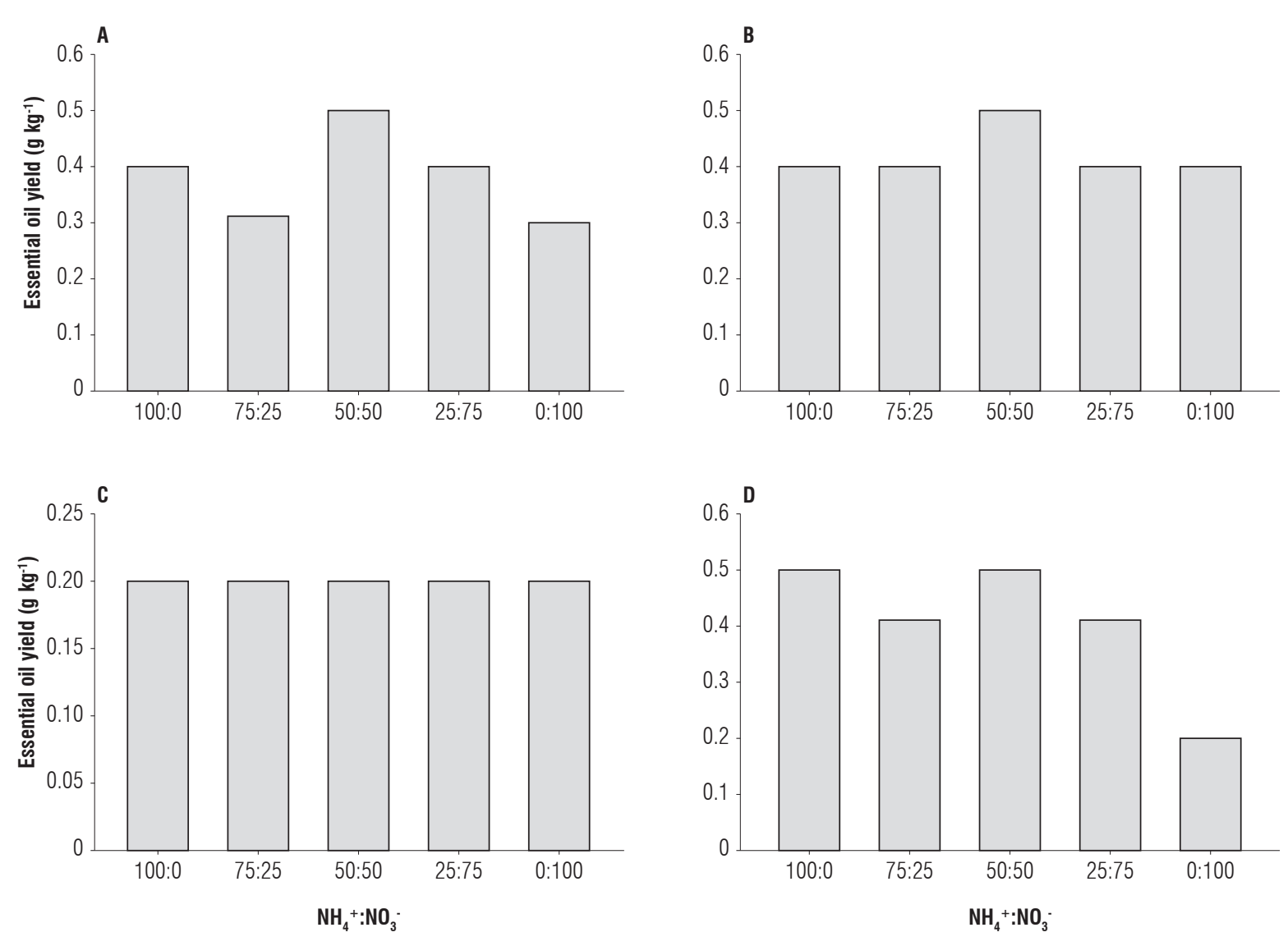

Figure 2. Essential oil yield $\left(\mathrm{g} \mathrm{kg}^{-1}\right)$ of Lippia alba plants grown with $\mathrm{NH}_{4}^{+}: \mathrm{NO}_{3}{ }^{-}$ratios and light enviroments: $\mathrm{A}$, aluminet mesh; B, red mesh; C, full sun; D, black mesh. 
Table 2. Chemical composition of the essential oil of lemon grass leaves (GC-MS: gas chromatography, GC-FID: gas chromatography coupled with flame ionization detection).

\begin{tabular}{|c|c|c|c|c|c|c|c|c|}
\hline \multirow{2}{*}{ Compound } & \multicolumn{2}{|c|}{ Full sun } & \multicolumn{2}{|c|}{ Red mesh } & \multicolumn{2}{|c|}{ Aluminet mesh } & \multicolumn{2}{|c|}{ Black mesh } \\
\hline & GC-MS & GC-FID & GC-MS & GC-FID & GC-MS & GC-FID & GC-MS & GC-FID \\
\hline \multicolumn{9}{|c|}{$\mathrm{NH}_{4}^{+}: \mathrm{NO}_{3}^{-}(100: 0)$} \\
\hline Myrcene & $\mathrm{pp}$ & $\mathrm{pp}$ & $n$ & $n$ & 1.16 & 2.36 & 1.94 & 2.76 \\
\hline$\rho$-cymene & $\mathrm{pp}$ & $\mathrm{pp}$ & 3.03 & 6.78 & 2.92 & 4.01 & 5.58 & 6.42 \\
\hline Linalool & $\mathrm{pp}$ & $\mathrm{pp}$ & 1.44 & 1.54 & 0.98 & 1.36 & 1.29 & 1.47 \\
\hline Neral & $\mathrm{pp}$ & $\mathrm{pp}$ & 35.19 & 33.44 & 35.37 & 35.79 & 35.33 & 32.82 \\
\hline Geraniale & $\mathrm{pp}$ & $\mathrm{pp}$ & 54.95 & 53.52 & 53.16 & 53.52 & 50.34 & 52.11 \\
\hline Caryophyllene oxide & $\mathrm{pp}$ & $\mathrm{pp}$ & 3.49 & 3.15 & 3.41 & 2.93 & 3.49 & 2.73 \\
\hline (E) -caryophyllene & $\mathrm{pp}$ & $\mathrm{pp}$ & 0.96 & 0.76 & $\mathrm{n}$ & $\mathrm{n}$ & 1.19 & 0.96 \\
\hline Terpinen-4-ol/E-isocitral & $\mathrm{pp}$ & $\mathrm{pp}$ & 0.98 & 0.76 & $\mathrm{n}$ & $\mathrm{n}$ & 0.84 & 0.70 \\
\hline \multicolumn{9}{|c|}{$\mathrm{NH}_{4}^{+}: \mathrm{NO}_{3}^{-}(75: 25)$} \\
\hline$\rho$-cymene & 1.17 & 1.97 & 1.42 & 2.49 & 2.41 & 3.50 & 5.87 & 5.96 \\
\hline Linalool & $\mathrm{n}$ & $\mathrm{n}$ & 0.94 & 1.27 & 0.95 & 1.26 & $\mathrm{n}$ & $\mathrm{n}$ \\
\hline Neral & 31.58 & 32.09 & 33.98 & 34.61 & 34.68 & 34.99 & 33.10 & 34.61 \\
\hline Geraniale & 58.20 & 57.49 & 56.86 & 56.15 & 56.13 & 55.36 & 57.44 & 57.18 \\
\hline Caryophyllene oxide & 6.06 & 5.27 & 4.88 & 4.20 & 4.01 & 3.41 & 3.59 & 2.23 \\
\hline (E) - caryophyllene & 1.66 & 1.71 & 0.92 & 0.77 & 1.01 & 0.98 & $n$ & $n$ \\
\hline Humulene epoxide II & 1.33 & 1.45 & 1.00 & 0.47 & 0.81 & 0.47 & $\mathrm{n}$ & $\mathrm{n}$ \\
\hline \multicolumn{9}{|c|}{$\mathrm{NH}_{4}^{+}: \mathrm{NO}_{3}^{-}(50: 50)$} \\
\hline Myrcene & $n$ & $n$ & $n$ & $n$ & 0.67 & 1.34 & 2.62 & 3.13 \\
\hline$\rho$-cymene & 1.61 & 2.76 & 3.04 & 2.54 & 3.18 & 3.95 & 7.33 & 7.35 \\
\hline Linalool & $\mathrm{n}$ & $\mathrm{n}$ & 1.70 & 1.32 & 1.11 & 1.28 & 1.70 & 1.28 \\
\hline Neral & 32.81 & 33.17 & 43.15 & 32.62 & 34.88 & 34.61 & 35.41 & 34.05 \\
\hline Carvone & $n$ & $\mathrm{n}$ & 9.08 & 5.41 & $\mathrm{n}$ & $n$ & $\mathrm{n}$ & $\mathrm{n}$ \\
\hline Geranial & 57.03 & 56.37 & 23.93 & 51.37 & 54.85 & 53.72 & 48.58 & 50.40 \\
\hline Caryophyllene oxide & 6.85 & 5.88 & 9.48 & 4.25 & 3.87 & 3.25 & 3.20 & 2.89 \\
\hline (E) - caryophyllene & 1.70 & 1.79 & 2.32 & 0.76 & 0.76 & 1.51 & $n$ & $n$ \\
\hline Terpinen-4-ol/E-isocitral & $\mathrm{n}$ & $n$ & $n$ & $\mathrm{n}$ & $n$ & $\mathrm{n}$ & 1.16 & 0.87 \\
\hline Humulene epoxide II & $\mathrm{n}$ & $n$ & 2.25 & 0.34 & 0.68 & 0.31 & $\mathrm{n}$ & $\mathrm{n}$ \\
\hline
\end{tabular}

pp: lost parcel; n: compound not detected.

It was also found that carvone (terpene ketone), a compound of great importance in L. alba leaves, was detected only in the plants grown under the red mesh and in the solution with 50:50 $\mathrm{NH}_{4}{ }^{+}: \mathrm{NO}_{3}{ }^{-}$; the eugenol compound only appeared in the plants grown under the aluminet mesh and in the $100 \% \mathrm{NO}_{3}{ }^{-}$solution (Ehlert et al., 2013).

Among the metabolites produced, terpenoids, in particular mono and sesquiterpenoids, have many functions in plants and are still poorly established for most isoprene derivatives since they involve thermoprotection effects, protection against oxidative damage, photorespiration at high temperatures and low concentrations of $\mathrm{O}_{2}$, allelopathy and photoprotection (Taiz and Zeiger, 2013).

While studying the composition of the essential oil in native plants of Lippia sidoides in the city of LavrasMG, Guimarães et al. (2014) found that the major constituents were carvacrol (26.44\%) and 1.8-cineol $(22.63 \%)$ 
Table 3. Chemical composition of essential oil of lemon grass leaves (GC-MS: gas chromatography, GC-FID: gas chromatography associated with flame ionization detection).

\begin{tabular}{|c|c|c|c|c|c|c|c|c|}
\hline \multirow{4}{*}{ Compound } & \multicolumn{8}{|c|}{$\mathrm{NH}_{4}^{+}: \mathrm{NO}_{3}^{-}(25: 75)$} \\
\hline & \multicolumn{2}{|c|}{ Full sun } & \multicolumn{2}{|c|}{ Red mesh } & \multicolumn{2}{|c|}{ Aluminet mesh } & \multicolumn{2}{|c|}{ Black mesh } \\
\hline & GC-MS & GC-FID & GC-MS & GC-FID & GC-MS & GC-FID & GC-MS & GC-FID \\
\hline & \multicolumn{8}{|c|}{$\%$} \\
\hline Myrcene & $n$ & $n$ & $n$ & $n$ & $n$ & $\mathrm{n}$ & 2,39 & 2,75 \\
\hline$\rho$-cymene & 3.52 & 3.56 & 3.01 & 7.57 & 4.95 & 5.70 & 8.22 & 8.75 \\
\hline Linalool & 1.74 & 1.08 & 1.24 & 1.64 & $\mathrm{n}$ & $n$ & 1.58 & 1.67 \\
\hline Neral & 39.76 & 32.89 & 32.51 & 34.32 & 39.22 & 41.95 & 35.75 & 33.56 \\
\hline Geranial & 45.01 & 56.19 & 55.99 & 52.39 & 53.70 & 48.93 & 47.99 & 49.59 \\
\hline Caryophyllene oxide & 8.01 & 5.25 & 6.13 & 3.39 & 2.13 & 3.39 & 4.08 & 3.65 \\
\hline Humulene epoxide II & 1.96 & 1.02 & 1.12 & 0.66 & $n$ & $n$ & $n$ & $n$ \\
\hline \multicolumn{9}{|c|}{$\mathrm{NH}_{4}^{+}: \mathrm{NO}_{3}^{-}(0: 100)$} \\
\hline Myrcene & $\mathrm{n}$ & $\mathrm{n}$ & $\mathrm{n}$ & $\mathrm{n}$ & $n$ & $n$ & 1.84 & 1.78 \\
\hline$\rho$-cymene & 3.88 & 2.87 & 2.08 & 2.39 & $\mathrm{n}$ & $\mathrm{n}$ & 6.46 & 6.71 \\
\hline Linalool & 2.33 & 1.36 & 0.87 & 0.65 & 0.99 & 1.14 & 1.54 & 1.53 \\
\hline Neral & 48.01 & 34.26 & 25.41 & 26.25 & 33.64 & 34.10 & 35.28 & 33.10 \\
\hline Geranial & 35.30 & 56.03 & 42.67 & 42.65 & 56.31 & 55.42 & 50.50 & 52.97 \\
\hline Caryophyllene oxide & 8.35 & 4.77 & 4.33 & 3.91 & 5.02 & 4.35 & 3.34 & 3.12 \\
\hline (E) - caryophyllene & $\mathrm{n}$ & $\mathrm{n}$ & $\mathrm{N}$ & $\mathrm{n}$ & 1.27 & 1.27 & $\mathrm{n}$ & $\mathrm{n}$ \\
\hline Terpinen-4-ol/E-isocitral & $\mathrm{n}$ & $\mathrm{n}$ & $\mathrm{N}$ & $\mathrm{n}$ & $\mathrm{n}$ & $n$ & 1.04 & 0.76 \\
\hline Umulene epoxide II & 2.13 & 0.69 & 0.80 & 0.61 & 0.94 & 0.87 & $n$ & $n$ \\
\hline Eugenol & $n$ & $n$ & $N$ & $n$ & 1.83 & 2.81 & $\mathrm{n}$ & $\mathrm{n}$ \\
\hline
\end{tabular}

$\mathrm{N}$ : compound not detected.

P-cymene, a compound that was detected in all treatments, is used as an antibacterial when combined with carvacrol, with synergy between them (Silva et al., 2010).

While studying the effect of different harvest schedules on the yield and composition of $L$. alba essential oil, Ehlert et al. (2013) observed that, between 8 and 10 a.m., the leaves presented the main components of the essential oil: carvone (49.48\%), limonene $(28.66 \%)$, sabinene $(2.25 \%)$, y-terpinene $(0.96 \%)$ linalool $(1.30 \%)$, elemol (3.62\%), and guaiol (0.56\%). It is worth noting that this study was carried out in São Paulo-SP (Brazil), where the environmental conditions are different, which may have led to the biosynthesis of components that were not observed in this experiment.

Essential oils are composed of a mixture of several compounds, and the contents of each depend on the environmental factors where the plant is grown (Andrade and Casali, 1999).
These plants have the potential to adapt to different luminosity and fertility conditions because of their phenotypic plasticity (Delgado and Lopez, 2008). The composition of these essential oils can be altered by the light conditions. Batista et al. (2016), while working with Lippia alba, verified that the composition of the volatile compounds varied with light quality and chemotype, with differences that were due mainly to the amounts of eucalyptol and linalool. As for $\mathrm{N}$ sources, Lima et al. (2017) found that there were significant interactions between light environments and ammonium and nitrate ratios in the nitrogen, phosphorus and potassium contents of Lippia alba plants.

\section{CONCLUSIONS}

Neral and geranial were found in higher concentrations in the essential oils in the solutions with 0:100 and 75:25 $\mathrm{NH}_{4}{ }^{+}: \mathrm{NO}_{3}{ }^{-}$, respectively, and under full sun, representing up to $90 \%$ of the total oil constituents. 
The red mesh and solution containing only $\mathrm{N}^{-N_{3}}$ - favored the production of eugenol. The aluminide mesh and 50:50 ratio of $\mathrm{NH}_{4}^{+}: \mathrm{NO}_{3}{ }^{-}$promoted the production of carvone. These compounds are of significant importance in the drug industry.

\section{ACKNOWLEDGMENTS}

The authors are grateful to Capes for funding the scholarship and developing the research.

Conflict of interests: this manuscript was prepared and revised with the participation of all the authors, who declare that they have no conflict of interests that could affect the validity of the results of the presented work.

\section{BIBLIOGRAPHIC REFERENCES}

Adams, R.P. 2007. Identification of essential oil components by gas chromatograpy/mass spectroscopy. $4^{\text {th }}$ ed. Allured Publishing Corporation, Carol Stream, IL.

Alves, C.A., N.F. Jesus, C.C.P. Silva, R.A. Santos, and S.G. Souza. 2013. Diagnose nutricional de mudas de girassol submetidas a proporções de amônio e nitrato. Encicl. Biosf. 9(16), 723-731.

Andrade, F.M.C. and V.W.D. Casali. 1999. Plantas medicinais e aromáticas: relação com o ambiente, colheita e metabolismo secundário. Departamento de Fitotecnia, Universidade Federal de Viçosa, Viçosa, Brazil.

Batista, D.S., K.M. de Castro, A.R. da Silva, M.L. Teixera, T.A. Sales, L.I. Soares, M.G. Cardoso, M.O. Santos, L.F. Viccini, and W.C. Otoni. 2016. Ligth quality affects in vitro growth and essential oil profile in Lippia alba (Verbenaceae). In Vitro Cell. Dev. Biol.-Plant 52(3), 276-282. Doi: 10.1007/s11627-016-9761-x

Bredemeier, C. and C.M. Mundstock. 2000. Regulação da absorção e assimilação do nitrogênio nas plantas. Ciênc. Rural 30(2), 365-372. Doi: 10.1590/ S0103-84782000000200029

Budavari, S. (ed.) 1989. Merck, the index: an encyclopedia of chemical, drugs and biologicals. Merck \& Co, Whitehouse Station, NJ.

Carmona, F., M.A. Angelucci, D.S. Sales, T.M. Chiaratti, F.B. Honorato, R.V. Bianchi, and A.M. Pereira. 2013. Lippia alba (Mill.) NE Brown hydroethanolic extract of the leaves is effective in the treatment of migraine in women. Phytomedicine 20(10), 947-950. Doi: 10.1016/j.phymed.2013.03.017

Chagas, J.H., J.E.B.P. Pinto, S.K.V. Bertolucci, A.G. Costa, H.C.R. Jesus, and P.B. Alves. 2013. Produção, teor e composição química do óleo essencial de hortelã-japonesa cultivada sob malhas fotoconversoras. Hortic. Bras. 31(2), 297-303. Doi: 10.1590/ S0102-05362013000200020

Corrêa, R.M., J.E.B.P. Pinto, E.S. Reis, C. Oliveira, E.M. Castro, and R.S. Brant. 2009. Características anatômicas foliares de plantas de orégano (Origanum vulgare L.) submetidas a diferentes fontes e níveis de adubação orgânica. Acta Sci., Agron. 31(3), 439-444. Doi: 10.4025/ actasciagron.v31i3.690

Delgado, C.A.A. and N.R. López. 2008. Plasticidad fenotípica em Lippia alba y Lippia origanoides (Verbenacea): Respuesta a la disponibilidad de nitrógeno. Acta biol. Colomb. 13(1), 53-64.

Ehlert, P.A.D., L.C. Ming, M.O.M. Marques, D.M. Fernandes, W.A. Rocha, J.M.O. Luz, and R.F. Silva. 2013. Influência do horário de colheita sobre o rendimento e a composição do óleo essencial de erva-cidreira brasileira [Lippia Alba (Mill.) NE Br.]. Rev. Bras. Plantas Med. 15(1), 72-77. Doi: 10.1590/S1516-05722013000100010

Guimarães, L.G.L., M.G. Cardoso, R.M. Souza, H.B. Zacaroni, and G.R. Santos. 2014. Óleo essencial de Lippia sidoides nativas de Minas Gerais: Composição, estruturas secretoras e atividade antibacteriana. Rev. Ciênc. Agron. 45(2), 267-275. Doi: 10.1590/ S1806-66902014000200006

Hoagland, D.R. and D.I. Arnon. 1950. The water-culture method for growing plants without soil. Circ. 347. California Agricultural Experimental Station, Berkeley, CA.

Lima, J.C., U.C. Oliveira, A.R. Santos, A.A. Souza, and G.S. Souza. 2017. Diagnose nutricional de Lippia alba (Mill) N. E. Br. cultivada sob proporções de amônio e nitrato e ambientes de luz. Rev. Ciênc. Agrár. 40(4), 770-776. Doi: 10.19084/RCA17148

Linde, G.A., N.B. Colauto, E. Albertó, and Z.C. Gazim. 2016. Quimiotipos, extracción, composición y aplicaciones del aceite esencial de Lippia alba. Rev. Bras. Plantas Med. 18(1), 191-200. Doi: 10.1590/1983-084X/15_037

Luz, J.M.Q., V.A. Santos, T.M. Rodrigues, M.F.A. Blank, and S.A. Asmar. 2014. Estabelecimento in vitro e aclimatização de Lippia alba (Mill.) NEBrown. Rev. Bras. Plantas Med. 16(2), 444-449. Doi: 10.1590/1983-084X/12_140

Matos, F.J.A. 2000. Plantas medicinais: guia de seleção e emprego de plantas usadas em fitoterapia no Nordeste do Brasil. $2^{\text {nd }}$ ed. UFC, Fortaleza, Brasil.

Meira, M.R., E.R. Martins, and S.A. Manganoti. 2012. Crescimento e produção de fitomassa e teor de óleo essencial de melissa (Melissa officinalis L.) sob diferentes níveis de sombreamento. Rev. Bras. Plantas Med. 14(2), 352-357. Doi: 10.1590/S1516-05722012000200015

Nascimento, W.D.M.C., O.F. Melo, I.F. Silva, and F.L. Souza. 2013. Plantas medicinais e sua utilização pelas comunidades do município de sobral ceará, Sanare. Rev. Polít. Públicas 12(1), 46-53. 
Ohse, S., D. Dourado Neto, P.A. Manfron, R.F. Otto, and A.R. Godoy. 2017. Rendimento e acúmulo de nitrato em alface hidropônica sob proporções de nitrato e amônio. Campo Digit@1: Rev. Ciências Exatas e da Terra e Ciências Agrárias 12(1), 52-64.

Oliveira, A.R.M.F., C.N. Jezler, R.A. Oliveira, M.S. Mielk, and C.B. Costa. 2012. Determinação do tempo de hidrodestilação e do horário de colheita no óleo essencial de menta. Hortic. Bras. 30(1), 155-159. Doi: 10.1590/ S0102-05362012000100026

Oliveira, V.C., A.R. Santos, G.S. Souza, G.R.F. Lima, P.B. Alves, and H.V. Santos. 2016. Metabólitos secundários e características anatômicas de folhas de orégano (Origanum vulgare ssp. hirtum) cultivado sob malhas coloridas. Rev. Ciênc. Agrár. 39(1), 170-177. Doi: 10.19084/ RCA15103

Pinto, J.E., E.O. Ferraz, K.V. Bertolucci, M.R.O. Silveira, A.R. Santos. and G.M. Silva. 2014. Produção de biomassa e óleo essencial em mil folhas cultivada sob telas coloridas. Hortic. Bras. 32(3), 321-326. Doi: 10.1590/ S0102-05362014000300014

Rajkumar, S. and A. Jebanesan. 2010. Chemical composition and larvicidal activity of leaf essential oil from Clausena dentata (Willd) M. Roam.(Rutaceae) against the chikungunya vector, Aedesaegypti Linn. (Diptera: Culicidae). J. Asia-Pacific Entomol. 13(2), 107-109. Doi: 10.1016/j.aspen.2010.02.001

Rao, B.R. 2001. Biomass and essential oil yields of rainfed palmarosa (Cymbopogon martinii (Roxb.) Wats. var. motia Burk.) supplied with different levels of organic manure and fertilizer nitrogen in semi-arid tropical climate. Ind. Crop Prod. 14(3), 171-178. Doi: 10.1016/ S0926-6690(01)00081-4
Santos, A.S. 2004. Descrição de sistema e de métodos de extração de óleos essenciais e determinação de umidade de biomassa em laboratório. Comunicado Técnico 99. EMBRAPA, Belém, Brazil.

Silva, J.P.L., J.M.D. Almeida, D.V. Perez, and B.D.G.M. Franco. 2010. Oleo essencial de oregano: interferencia da composicao quimica na atividade frente a Salmonella enteritidis. Ciênc. Tecnol. Aliment. 30(1), 136-141. Doi: 10.1590/S0101-20612010000500021

Soares, B.V. and M.T. Dias. 2013. Espécies de Lippia (Verbenaceae), seu potencial biotivo e importância na medicina veterinária e aquicultura. Biota Amazônia 3(1), 109-123. Doi: 10.18561/2179-5746/biotaamazonia. v3n1p109-123

Souza, M.F., P.A. Gomes, I.T. Souza Junior, M.M. Fonseca, C.S. Siqueira, L.S. Figueiredo, and E.R. Martins. 2007. Influência do sombreamento na produção de fitomassa e óleo essencial em alecrim-pimenta (Lippia sidoides Cham.). Rev. Bras. Biociênc. 5(2), 108-110.

Souza, G.S., J.E.B.P. Pinto, M.G. Resende, S.K.V. Bertolucci, Â.M. Soares, and E.M. Castro. 2011. Crescimento, teor de óleo essencial e conteúdo de cumarina de plantas jovens de gauco (Mikania glomerata Sprengel) cultivadas sob malhas coloridas. Biotemas 24(3), 1-11. Doi: 10.5007/2175-7925.2011v24n3p1

Taiz, L. and E. Zeiger. 2013. Fisiologia vegetal. $5^{\text {th }}$ ed. Artmed, Porto Alegre, Brazil.

Tavares, I.B., V.G. Monmenté, and I.R. Nascimento. 2011. Lippia alba; estudos químicos, etnofarmacológicos e agronômicos. Rev. Bras. Tecnol. Aplicada Ciênc. Agrár. 4(1), 204-220. Doi: 10.5777/PAeT.V4.N1.12 